\title{
Emerging Adulthood in Brazilians of Differing Socioeconomic Status: Transition to Adulthood ${ }^{1}$
}

\author{
Luciana Dutra-Thomé2 \\ Universidade Federal do Rio Grande \\ do Sul, Porto Alegre-RS, Brazil
}

\author{
Silvia Helena Koller \\ Universidade Federal do Rio Grande \\ do Sul, Porto Alegre-RS, Brazil
}

\begin{abstract}
This study was a descriptive exploratory investigation into the transition to adulthood in Brazilian young people of differing socioeconomic status (SES), considering the phenomenon of Emerging Adulthood (EA). The variables analyzed were sociodemographic aspects, perceptions of adulthood, access to technology, and educational and employment status. The sample included 547 young people ranging between 18 and 29 years of age, residents of Porto Alegre (RS), of low and high SES. More than $50 \%$ of the total sample reported that they felt in-between adolescence and adulthood, which may indicate the existence of EA in individuals of both SES. However, EA was more likely to be present in high SES contexts. The low SES group presented a tendency to assume adult responsibilities earlier, which blocks their opportunities for experiencing a period of identity exploration.
\end{abstract}

Keywords: adult development, young adults, adults

\section{Adultez Emergente em Brasileiros de Diferentes Níveis Socioeconômicos: Transição Para a Vida Adulta}

\begin{abstract}
Resumo: O presente estudo constituiu investigação exploratória descritiva de caráter tranversal sobre transição para a vida adulta em brasileiros de diferentes níveis socioeconômicos (NSE), considerando o fenômeno chamado adultez emergente (AE). Foram analisadas variáveis sociodemográficas, percepção de adultez, acesso à tecnologia, status educacional e de trabalho. A amostra foi composta de 547 jovens de ambos os sexos, residentes em Porto Alegre (RS), entre 18 e 29 anos, e pertencentes aos NSEs baixo e alto. Mais de $50 \%$ da amostra total registrou perceber-se ambivalente quanto a ter atingido ou não a vida adulta, o que pode indicar a existência da $\mathrm{AE}$ em indivíduos de ambos NSEs. Todavia, a AE mostrou-se mais provável de ocorrer em contextos de NSE alto. O grupo de NSE baixo apresentou tendência a assumir responsabilidades adultas precocemente, o que dificulta a experimentação de um período mais exploratório de suas identidades.
\end{abstract}

Palavras-chave: desenvolvimento do adulto, jovens, adultos

\section{Adultez Emergente en Brasileños de Diferentes Niveles Socioeconómicos: Transición Para la Vida Adulta}

\begin{abstract}
Resumen: Este estudio constituyó una investigación exploratoria descriptiva de carácter trasversal sobre la transición para la vida adulta en brasileños de diferentes niveles socioeconómicos (NSE), considerando el fenómeno llamado de adultez emergente (AE). Fueron analizadas variables sociodemográficas, como percepción de adultez, tiempo libre, acceso a la tecnología, nivel educativo y estatus laboral. La muestra fue compuesta por 547 jóvenes de ambos sexos, residentes en Porto Alegre (RS), entre 18 y 29 años; de NSE bajo y alto. Más del 50\% de la muestra total señaló percibirse ambivalente en cuanto a haber llegado o no a la vida adulta, lo que puede indicar la presencia de la AE en sujetos de ambos NSEs. Sin embargo, la AE se mostró más probable de ocurrir en contextos de NSE alto. El grupo de NSE bajo presentó tendencia a asumir responsabilidades adultas precozmente, lo que dificulta la experimentación en un período más exploratorio de sus identidades.
\end{abstract}

Palabras clave: desarrollo del adulto, jóvenes, adultos.

The concept of emerging adulthood (EA) arose in the last decade in the context of developmental psychology. It refers to the period subsequent to adolescence, when young people are

\footnotetext{
1 Support: Coordination for the Improvement of Higher Education Personnel (CAPES) and National Council for Scientific and Technological Development (CNPq - Process No. 200113/2011-9).

2 Correspondence address:

Luciana Dutra-Thomé. Instituto de Psicologia, Universidade Federal do Rio Grande do Sul. Rua Ramiro Barcelos, 2600/104. CEP 90035-003. Porto Alegre-RS, Brazil. E-mail: luciana.thome@ufrgs.br
}

gradually preparing themselves to enter adult life. This recent concept is related to changes in industrialized Western countries, such as the advent of the contraceptive pill, tolerance of premarital sex, technological advances, and the increase in the years dedicated to professional qualification, among others (Arnett, 2005). These changes increased the options to be explored by young people between 18 and 29 years of age, since they began to have greater freedom in central fields of their lives, such as employment and loving relationships. Due to these factors, the period between adolescence and adulthood was extended. 
Investigations into this subject are important, considering that the youth public is the target of public policies that seek to promote their social and work inclusion (Brazilian Institute of Geography and Statistics [IBGE], 2011; Ministry of Education, 2011). These aspects make this study relevant, which investigates EA in the Brazilian urban context, considering that (a) there are few studies that consider socioeconomic differences among emerging adults (Arnett \& Tanner, 2011); and (b) although there are studies on EA in Argentina, Mexico and Chile (Arias \& Hernandez, 2007; Facio, Resett, Micocci, \& Mistrorigo, 2007), studies on the subject in Latin America and Brazil remain scarce (Galambos \& Martínez, 2007).

\section{The Concept of EA}

The psychosocial development theory proposed by Erikson $(1950,1968)$ has been a widely used reference for comprehending adolescence and the transition to adulthood. Erikson defined adolescence as the developmental stage that lasts from puberty until approximately the age of 20 years, followed by the stage called "young adulthood", which lasts until age 40. He also developed the concept of "psychosocial moratorium" a period of adolescence associated with biological maturity and the intellectual capacity for abstraction. In this phase, young people are encouraged to assume several roles, exploring their identity, both individually and in the relationship with their peers.

As an update to the proposal of Erikson, a new concept arose to explain the increasing complexity of the experience of entering into present adult life: EA. This is a distinct period of adolescence and adulthood, being an extension of the transition to the latter. It is emphasized that such an experience is only observed in cultures that allow young people a prolonged period of exploration of their identities in dimensions such as love and work. Therefore, the concept considers the characteristics associated with the new dynamics of life of adolescents in industrialized societies (e.g., greater investment in professional qualification and pre-marital sex) (Arnett, 2011; Arnett \& Eisenberg, 2007).

In sociodemographic terms, EA presents nonnormative characteristics when compared with the sociodemographic homogeneity that adolescence and adulthood tend to present in Western industrialized societies. During adolescence, the majority of young people experience changes driven by puberty, study in high school, live with their parents and are monitored by adults. In adulthood, in turn, people tend to be married, with children and a stable job. Conversely, EA is demographically heterogeneous, with no clear normative reference (Arnett, 2011). For example, in the United States, the residential status of young people between 18 and 29 years can manifest in several ways: some leave the parental home to live in college dorms, experiencing semi-autonomy, as they still have parental support. Other young people leave home to work or to live with a loving partner and there are those who remain living with their parents until marriage (Goldscheider \& Goldscheider, 1994).

In Brazil, some data on residential status have indicated an extension of the presence of the children with their parents. The proportion of people 25-34 years of age who still live with their parents increased from $20.5 \%$ in 2002 to $24.5 \%$ in 2012 (IBGE, 2013). The economic factor was shown to be predominant in this context. It was observed that the proportion of young people living with their parents increased according to the household income. Only $6.6 \%$ of households with a per capita income of up to half the minimum wage had children aged between 25 and 34 years living with their parents. This proportion rose to $15.3 \%$ in families with incomes of two to five minimum wages per capita, and $14.7 \%$ for those with a per capita income of more than five minimum wages. The fact that the low-income bands are composed of younger families partly explains this difference (IBGE, 2013).

In addition to the sociodemographic heterogeneity, emerging adults have specific subjective characteristics, such as the feeling of "ambivalence", generated by having characteristics of adolescents and of adults. In addition to not being fully considered adults, the acquisition of typical adulthood roles (e.g., stable residence and completion of studies) is not associated with their concepts of what it means to reach this stage. The three main aspects considered by them as important criteria to achieve adulthood are: (a) assumption of responsibility for oneself, (b) making independent decisions, and (c) financial independence. The first two criteria were classified as individual character qualities, due to focusing on the importance of becoming a selfsufficient person. Financial independence, in turn, is crucial to attain self-sufficiency, and is more associated with achieving a function associated with adulthood, such as having children and leaving the parental home, rather than a character quality (Arnett, 2011).

Emerging adulthood is also characterized by a period of exploration of the identity, in which young people seek to experience a diversity of experiences, full of intensity and novelty, before assuming the commitments of adulthood. This exploration occurs throughout adolescence, however, from this moment, young people experience a gradual conquest of autonomy and decreased parental monitoring, which allows them access to new experimentation with themselves. In terms of exploration of identity, adolescents tend toward more recreational experimentation, since they are not necessarily focused on the commitments directly associated with the assumption of adult roles. In EA the exploratory attitude is more oriented toward the future, 
and the gradual process of assuming commitments. Furthermore, emerging adults are in the process of re-examining their own beliefs and reconstructing their worldviews, which are influenced by the experiences of university and work contexts. While they are exploring different experiences, they simultaneously face feelings of frustration and instability in relation to themselves, since they can move closer to or away from their expectations. Related to this are the empirical findings that, at the stage of EA, subsequent to adolescence, risk behaviors reach their peak (unprotected sex, drug use, etc.) (Arnett, 2011).

Five core characteristics of EA have been identified: (a) Stage of identity exploration, since the young people are taking important decisions in the areas of love and work, seeking to integrate interests and preferences given the opportunity; (b) Period of instability, related to the changes they experience in the exploration of different experiences; (c) Age of focusing on themselves, since they have fewer commitments (e.g., not being married and not having a stable job) and more possibilities to decide for themselves; (d) Feelings of ambivalence, because there no longer feel themselves to be adolescents nor entirely adults; and (e) Phase of possibilities, because no matter their current situation, they believe that they will achieve the life that they idealize (Arnett, 2011).

These characteristics are based on studies conducted in the USA and should not be taken as universal, as they do not necessarily apply to other contexts. In developing countries, only a portion of young people experience EA, with these tending to belong to medium and high socioeconomic groups and from urban areas. In Latin America, for example, EA is present in the more affluent layers of society, however, is not normative on this continent (Galambos \& Martínez, 2007). In Brazil, the postponement of traditional adult roles and the possibility for the exploitation of identities does not apply to all socioeconomic levels and cultural realities of the country.

\section{Adolescence and EA: Transition to Adulthood}

The symbols and discourses associated with the concept of youth (e.g., specific clothing, signs and attitudes) are manifested in the lives of adolescents and emerging adults, acquiring cultural particularities (Margulis \& Urresti, 2008). In Brazil, aspects that converge for the manifestation of the phenomenon of EA in the country can be observed, such as the current changes in the family structure. Conversely, characteristics of the Brazilian social structure hinder the appearance of EA, such as the premature inclusion into the labor market of a significant proportion of young people (Guimarães \& Romanelli, 2002; Marques, Neves \& Carvalho Neto, 2002).

Regarding the convergent aspects, the current changes in the structure of families are characterized by a more complex transition to adulthood, due to the late departure of children from the home. Dialogue and freedom in family relationships have generated a new form of adulthood constitution. Traditional family values coexist with the individual values of each family member, and emerging adults tend to gain a level of autonomy never achieved in previous decades (Borges \& Magalhães, 2009; Vieira \& Rava, 2010; Zordan, Falcke, \& Wagner, 2009). These elements may influence the feeling of ambivalence experienced by emerging adults. On one hand, they seek independence and want to assume adult roles, while, on the other, they live with their parents and need to respect certain family rules.

Regarding the aspects that hinder the manifestation of EA in Brazil, contextual weaknesses in the social structure of the country are prominent. Young people, aged between 18 and 24 years, face difficulties entering the labor market, prejudice and low levels of educational (Câmara, Castellá Sarriera, \& Pizzinato, 2004; IBGE, 2011), especially those of low socioeconomic status (SES). Low SES families tend to encourage their children to work so they have individual responsibility regarding their own expenses and can contribute to the family income, without considering the associated risk factors, such as damage to health, identity formation and academic performance (Amazarray, Dutra-Thomé, Souza, Poletto, \& Koller, 2009; Arnett, 2011; Guimarães \& Romanelli, 2002; Marques et al., 2002).

Given the above, the present study aimed to investigate the transition to adulthood of Brazilian youths of high and low SES, and to verify similarities and differences between these groups. This was a descriptive cross-sectional study based on exploratory research regarding the transition to adulthood.

\section{Method}

\section{Participants}

The participants were 547 Brazilian youths; living in Porto Alegre, Rio Grande do Sul, between 18 and 29 years of age $(M=22$ years; IQ = 19-26), $196(35.8 \%)$ males and $351(64.2 \%)$ females, with low $(n=194$, $35.5 \%)$ and high SES $(n=353,64.5 \%)$. For the SES definition, the socioeconomic classification of the Brazilian Association of Market Research Institutes (ABIPEME, 2008) was used. This classification assigns scores to items of domestic comfort (such as washing machine, refrigerator and television) and the educational level of the head of the family. In this study, the head of the family corresponded to the parent that had the higher educational level. In addition, the automobile domestic comfort item was included, due to the participation of young people over 18 years of age, who are legally allowed to drive in Brazil. 


\section{Instrument}

Brazilian Questionnaire on Brazilian Youth, second version (Dell'Aglio, Koller, Cerqueira-Santos, \& Colaço, 2011), which is part of a national investigation into risk and protective factors in young people, organized by the Youth, Resilience and Vulnerability group of the National Association for Research and Graduate Studies in Psychology (ANPEPP). The instrument contains 77 questions, from which the following variables were selected: sociodemographic (gender, skin color, marital status, residential status, contribution to family income, and SES), access to technology, educational situation, and employment situation. Two questions were added to the questionnaire: perception of adulthood and criteria for achieving adulthood.

\section{Procedure}

Data collection. Educational institutions were accessed aiming to include young people of different SES, these being: (a) two technical courses, (b) three universities, (c) two preuniversity courses, and (d) two youth and adult education schools. Young people from contexts of extreme poverty or wealth were not part of these institutions. Consequently, the young people that responded to the questionnaire were of medium-low and medium-high SES, these groups being less contrasting, which allowed the investigation of more subtle differences between them.

The study questionnaire was digitized and applied in two ways: virtual and in-person. In the first case, the questionnaires were sent by e-mail or accessed online from the website of the research group. In the second case, the questionnaires were administered in the computer laboratories of the institutions, having, in some cases, 10 to 15 participants, and in others, more than 30 , depending on the size of the room. The in-person application aimed to support the young people who could have difficulty comprehending the questions of the questionnaire. The average time to complete the questionnaire was one hour.

The aims of the study and the research group were presented to the institutions. Those participants who took part in the in-person data collection signed the Institutional Terms of Agreement. Before the collection, the following aspects were described to the participants: the nature of the study, the confidentiality of the information shared, and the data analysis process. Next, the Informed Consent Form was read. In the institutions where the data collection was only performed virtually, a meeting with the potential participants was carried out, in which they were invited to participate in the study and, if interested, could register their email address on a list. In these cases, the Informed Consent Form was accessed from the online platform.

Data analysis. Descriptive statistics and bivariate analyzes were performed to compare the young people of high and low SES: chi-square, to measure associations between variables; and Student's t-test to compare means between groups. The variables analyzed were: sociodemographic data (gender, skin color, marital status, residential status, contribute to family income, and SES), perception of adulthood, criteria for achieving adulthood, employment status, educational status, and access to technology.

\section{Ethical Considerations}

The project was approved by the Research Ethics Committee of the Instituto de Psicologia of the Universidade Federal do Rio Grande do Sul under Process No. 2011014. All the participants signed the Informed Consent Form in agreement with Resolution No. 196 (Ministry of Health, 1996) and Resolution No. 016 (Federal Council of Psychology, 2000).

\section{Results}

Regarding the sociodemographic characteristics, the low SES group was mainly comprised by minority groups, which, in this study, refers to the population composed of people of black, brown, yellow and red skin color, and by participants from non-university institutions (Tables 1 and 2). The low SES group showed a higher frequency of contributing to the family income (21.1\%) compared to the high SES group (3.1\%). This group, in turn, presented a higher frequency of responses in relation to relying on contributions from others $(53.3 \%)$ compared to the low SES group, in which the percentage was $38.7 \%[\chi 2(2, N=547)=48.7, p=.001]$ (Table 1$)$.

With regard to marital status, the low SES group presented the status of married $(7.2 \%)$ and cohabitating (9.8\%) more often than the high SES group $(3.4 \%$ and $5.9 \%$, respectively). The high SES group showed a higher frequency of the single status $(90.7 \%)$, compared to the low SES group $(82.9 \%)[\chi 2(3, N=547)=9.14, p=.027]$. These results indicate the trend for the low SES group to assume adult roles earlier, being committed to stable relationships and cohabitation, in comparison to the young people of the high SES group (Table 1).

The findings related to the residential situation also reinforce the assumption of adult roles by young people from the low SES group. As shown in Table 1, the high SES group had higher frequencies of living with the father, mother, and brothers, while the low SES group had higher frequencies of living with children, husband/wife and alone.

Regarding the perception of adulthood, the low SES group seemed to assume adult roles before the high SES group, since they presented higher percentages of marriage or cohabitation; others resided alone; a portion had children, and they tended to be working (Table 1). Proportionally, the young people of the low SES group presented a higher frequency of perception of having reached adulthood (40.2\%) than the young people of the high SES group (21.2\%). In the high SES group the rates of young people who did not perceive themselves to be adults (18.4\%), and who perceived themselves to be in-between adolescence and adulthood 
Dutra-Thomé, L., \& Koller, S. H. (2014). Emerging Adulthood in Differing Socioeconomic Status.

Table 1

Sociodemographic Characteristics: Gender, Skin Color, Age, Marital Status, Residential Status, Family Income

\begin{tabular}{|c|c|c|c|c|}
\hline & Total & Low SES & High SES & $p^{a}$ \\
\hline & $N(\%)$ & $n(\%)$ & $n(\%)$ & \\
\hline Gender & & & & .576 \\
\hline Male & $196(35.8)$ & $66(34)$ & $130(36.8)$ & \\
\hline Female & $351(64.2)$ & $223(63.2)$ & $128(66)$ & \\
\hline Skin color & & & & .001 \\
\hline Majority group (White) & $449(82.1)$ & $139(71.6)$ & $310(87.8)$ & \\
\hline Minority group (Black, Brown, Yellow, Red) & $98(17.9)$ & $55(28.4)+$ & 43 (12.2)- & \\
\hline Age $\left(\text { median, } \mathrm{IQ}^{\mathrm{b}}\right)^{\mathrm{c}}$ & $22(19-26)$ & $22(19-26)$ & $22(19-25)$ & .244 \\
\hline Marital status & & & & .027 \\
\hline Single & $480(87.9)$ & $160(82.5)-$ & $320(90.7)+$ & \\
\hline Married & $26(4.8)$ & $14(7.2)+$ & $12(3.4)-$ & \\
\hline Cohabitating & $40(7.3)$ & $19(9.8)+$ & $21(5.9)-$ & \\
\hline Separated/divorced & $1(0.2)$ & $1(0.5)$ & $0(0.0)$ & \\
\hline \multicolumn{5}{|l|}{ Residential situation: with whom do you live? } \\
\hline Father & $252(46.1)$ & 55 (28.4)- & $197(55.8)+$ & .001 \\
\hline Mother & $356(65.1)$ & 89 (45.9)- & $267(75.6)+$ & .001 \\
\hline Stepfather & $22(4.0)$ & $7(3.6)$ & $15(4.2)$ & .715 \\
\hline Stepmother & $5(0.9)$ & $2(1.0)$ & $3(0.8)$ & .827 \\
\hline Siblings & $238(43.5)$ & $64(33.3)-$ & $174(49.3)+$ & .001 \\
\hline Grandmother ${ }^{d}$ & $27(4.9)$ & $7(3.6)$ & $20(5.7)$ & .288 \\
\hline Grandfather & $8(1.5)$ & $3(1.5)$ & $5(1.4)$ & .904 \\
\hline Uncles & $16(2.9)$ & $5(2.6)$ & $11(3.1)$ & .721 \\
\hline Children & $26(4.8)$ & $19(9.8)+$ & $7(2.0)-$ & .001 \\
\hline Partner & $42(7.7)$ & $17(8.8)$ & $25(7.1)$ & .480 \\
\hline Husband/wife & $31(5.7)$ & $18(9.3)+$ & $13(3.7)-$ & .007 \\
\hline Friends & $20(3.7)$ & $10(5.2)$ & $10(2.8)$ & .116 \\
\hline Alone & $47(8.6)$ & $33(17.0)+$ & $14(4.0)-$ & .001 \\
\hline Who contributes most to the household income? & & & & .001 \\
\hline Yourself & $52(9.5)$ & $41(21.1)+$ & $11(3.1)-$ & \\
\hline All & $231(42.2)$ & $78(40.2)$ & $153(43.3)$ & \\
\hline Others & $264(48.3)$ & 75 (38.7)- & $189(53.3)+$ & \\
\hline
\end{tabular}

Note. ${ }^{\mathrm{a}}$ Chi-square test; ${ }^{\mathrm{b} I n t e r q u a r t i l e ~ r a n g e ~(I Q): ~ I n t e r q u a r t i l e ~ r a n g e ; ~}{ }^{\mathrm{c}}=542 ;{ }^{\mathrm{d}}=54$; bold indicates $p<.05 ;+=$ Adjusted standardized residual $>+1.96 ;-=$ Adjusted standardized residual $<-1.96$.

$(60.3 \%)$ were higher compared to the low SES group $(9.3 \%$ and $50.5 \%$, respectively) $[\chi 2(2, N=547)=25.1, p=.001]$.

The results highlight that over $50 \%$ of the total sample reported feeling in-between adolescence and adulthood (Figure 1). This may indicate that the young people of both SES presented the feeling of ambivalence, a subjective feature of EA.

Nine criteria for achieving adulthood were investigated:(a) completing education, (b) marrying, (c) having children, (d) leaving the parental home, (e) accepting responsibility for oneself, (f) making independent decisions, (g) becoming financially independent, (h) beginning to have more consideration for others, and (i) becoming able to take care of their parents. When asked which of these criteria they considered important to reach adulthood, statistically significant differences were only observed in relation to the criteria of becoming able to take care of their parents, in which the low SES group presented higher frequencies $(22.2 \%)$ compared to the high SES group (15\%) $[\chi 2(1, N=547)=4.42, p=.035]$. When asked about the most important criteria for achieving adulthood, considering the total sample (high and low SES groups, Figure 2), the criterion of accepting responsibility for oneself was identified as the most important to reach adulthood, followed by becoming financially independent and completing education.

In relation to access to technology, the high SES group presented higher frequencies of use of contract cell phones $(41.6 \%)[\chi 2(1, N=547)=17.6, p=.001]$; Cable TV $(56.1 \%)[\chi 2(1, N=547)=46.4, p=.001]$, as well as internet access at home $(94.6 \%)[\chi 2(1, N=547)=74.1, p=.001]$ and in the educational institution they attended (49.9\%) $[\chi 2(1, N=547)=8.20, p=.004]$. The low SES group presented, respectively, the following percentages: $23.7 \%$, $25.8 \%, 67.0 \%$, and $37.1 \%$. 


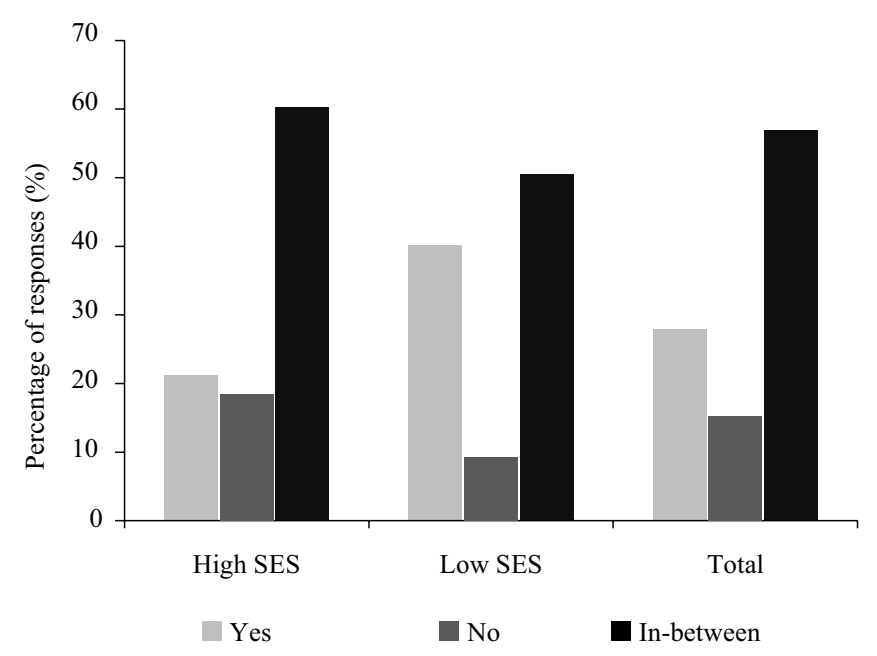

Figure 1. Percentages of responses regarding the perception of having reached adulthood for the high and low SES groups and the total sample.

Regarding the use of the internet, the high SES group presented a higher frequency of use to "communicate with people" (96.6\%) compared to the low SES group (89.2\%) $[\chi 2(1, N=504)=12.1, p=.001]$ and showed a higher frequency of use for "Downloading music, games and movies" (68.8\%) compared to the low SES group (58.8\%) $[\chi 2(1, N=504)=5.60, p=.018]$. Furthermore, the high SES group presented a higher percentage of use of the internet "for work purposes" $(89.8 \%)$ compared to the low SES group $(77.3 \%)[\chi 2(1, N=504)=15.6, p=.001]$. They also presented a higher frequency of use to "navigate their sites of interest" (85.6\%) compared to the low SES group (72.7\%) $[\chi 2(1, N=504)=13.4, p=.001]$. The high SES group also presented a higher frequency of use of the internet to "buy things" (37.7\%) compared to the low SES group (20.6\%) $[\chi 2(1, N=504)=13.4, p=.001]$.

Compared to the high SES group, the low SES group presented a higher percentage of participants with access to pre-paid cell phones (72.2\%), $[\chi 2(1, N=547)=7.64, p=.06]$, and who used the internet in cyber cafes $(21.1 \%),[\chi 2(1, N=547)=35.1, p=.001]$. The high SES group presented the following percentages, respectively $60.3 \%$ and $4.8 \%$.

With regard to employment and educational status, the low SES group presented higher percentages of being enrolled in Elementary Education (12.9\%), High School Education/Technical school (18\%), and stopped studying after High School Education (6.7\%), than the high SES group (Table 2). This group, in turn, had a higher percentage of being at University (65.2\%) compared to the low SES group $(42.8 \%)[\chi 2(7, N=547)=56.7, p=.001]$. These results indicate that individuals of high SES have a higher frequency of access to further education. Regarding the period of study, the high SES group presented a higher

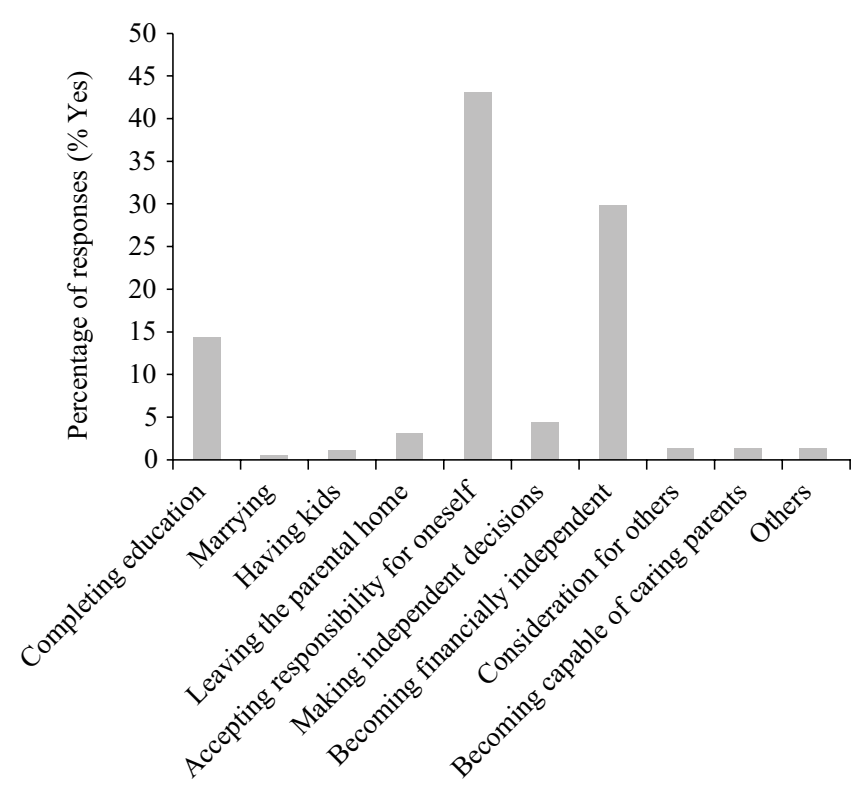

Figure 2. Percentages of positive responses in relation to the most important criteria to reach adulthood $(N=547)$.

percentage of fulltime study (12.4\%) than the low SES group $(4.9 \%)[\chi 2(1, N=547)=6.01, p=.014]$.

Regarding the work situation, the low SES group showed a higher frequency of "working" $(58.2 \%)$ compared to the high SES group $(49.0 \%)[\chi 2(1, N=547)=4.28 p=.038]$. Furthermore, the low SES group presented a higher percentage of work in shops $(12.9 \%)$ than the high SES group $(4.5 \%)$, $[\chi 2(1, N=547)=12.6, p=.001]$.

\section{Discussion}

Regarding the sociodemographic characteristics, the low SES group was mainly composed of people of black, brown, yellow and red skin color (Table 1), and of participants from non-university institutions (Tables 1 and 2). Some of these young people are part of minority groups who have faced discrimination and impairments over the years (Arnett, 2010; Casal \& Farias, 2005). The difficulty of access to higher levels of educational is an example of a problem faced by these groups. This creates an educational gap that tends to block employment opportunities, since organizations generally demand high educational and professional levels for obtaining a quality work position of higher status. However, the difficulty of inclusion in the labor market also affects people with a high educational level, in Brazil and in other countries (Câmara et al., 2004; Lopes, 2012).

These results were reinforced when data regarding Employment and Educational Status were analyzed. The high SES group had higher educational levels, with a higher percentage of individuals attending university and studying full time. The low SES group, in turn, had lower educational levels and higher rates of school year repetition. This 
Dutra-Thomé, L., \& Koller, S. H. (2014). Emerging Adulthood in Differing Socioeconomic Status.

Table 2

Percentage Relating to Employment Status, Educational Situation, Institution, Period of Study, and School Year Repetition (N=547)

\begin{tabular}{|c|c|c|c|c|}
\hline & Total & Low SES & High SES & \multirow{2}{*}{$p^{a}$} \\
\hline & $N(\%)$ & $n(\%)$ & $n(\%)$ & \\
\hline \multicolumn{5}{|l|}{ Work situation } \\
\hline I have never worked & $95(17.4)$ & $29(14.9)$ & $66(18.7)$ & .268 \\
\hline I have worked, but I am not looking for work at the moment & $111(20.3)$ & $34(17.5)$ & $77(21.8)$ & .233 \\
\hline I am working & $286(52.3)$ & $113(58.2)+$ & $173(49.0)-$ & .038 \\
\hline I am looking for work & $98(17.9)$ & $36(18.6)$ & $62(17.3)$ & .772 \\
\hline I am not looking for work & $37(6.8)$ & $9(4.6)$ & $28(7.9)$ & .142 \\
\hline I work in shops/markets & $41(7.5)$ & $25(12.9)+$ & $16(4.5)-$ & .001 \\
\hline \multicolumn{5}{|l|}{ Educational situation ${ }^{\mathrm{b}}$} \\
\hline Yes, I am in Elementary Education & $33(6.0)$ & $25(12.9)+$ & $8(2.3)-$ & \\
\hline Yes, I am in High School/Technical School & $79(14.4)$ & $35(18.0)+$ & $44(12.5)-$ & \\
\hline Yes, I am in University/Technological course & $313(57.2)$ & $83(42.8)-$ & $230(65.2)+$ & \\
\hline Yes, I am in a Graduate program & $51(9.3)$ & $19(9.8)$ & $32(9.1)$ & \\
\hline No, because I had to interrupt my studies & $9(1.6)$ & $7(3.6)+$ & $2(0.6)-$ & .001 \\
\hline No, because I already concluded Elementary Education & $2(0.4)$ & $0(0.0)$ & $2(0.6)$ & \\
\hline No, because I already concluded High School & $18(3.3)$ & $13(6.7)+$ & $5(1.4)-$ & \\
\hline $\begin{array}{l}\text { No, because I concluded University/ Technical School / } \\
\text { Technological course }\end{array}$ & $42(7.7)$ & $12(6.2)$ & $30(8.5)$ & \\
\hline \multicolumn{5}{|l|}{ Institution $^{\mathrm{c}}$} \\
\hline University & $245(61.6)$ & 74 (49.0)- & $171(69.2)+$ & .001 \\
\hline Non-university & $153(38.4)$ & $77(51.0)+$ & $76(30.8)-$ & \\
\hline \multicolumn{5}{|l|}{ Study period ${ }^{\mathrm{d}}$} \\
\hline Morning & $75(17.6)$ & $27(18.9)$ & $48(17.0)$ & .635 \\
\hline Afternoon & $126(29.6)$ & $40(28.0)$ & $86(30.5)$ & .590 \\
\hline Full time & $42(9.9)$ & 7 (4.9)- & $35(12.4)+$ & .014 \\
\hline Night & $246(57.9)$ & $83(58.0)$ & $163(57.8)$ & .962 \\
\hline \multicolumn{5}{|l|}{ School year repetition ${ }^{\mathrm{e}}$} \\
\hline Yes & $161(29.7)$ & $73(38.0)+$ & $88(25.1)-$ & .002 \\
\hline
\end{tabular}

Note. ${ }^{\mathrm{a}}$ Chi-square test ${ }^{\mathrm{b}}=398 ;{ }^{\mathrm{c}}=398 ;{ }^{\mathrm{d}}=425{ }^{\mathrm{e}}=543$; bold indicates $p<.05 ;+=$ Adjusted standardized residual $>+1.96 ;-=$ Adjusted standardized residual $<-1.96$.

finding was probably related to the fact that the low SES group showed a higher frequency of "currently working" compared to the high SES group (Table 2), possibly due to their tendency to work to contribute to the family income or take responsibility for their own expenses. The type of work they perform can limit the time they are able to dedicate to studies and leisure activities.

The higher percentage of perceptions of having reached adulthood for the low SES group, compared to the high SES group, could be due to the influence of assuming adult roles earlier and the socioeconomic specificities of their contexts. Those of low SES tend to assume adult roles prematurely, due to the need to help their parents with the family income from adolescence. In Brazil, the parents of low SES families tend to understand that their obligation to provide their children's education has been fulfilled when the child finishes Elementary Education and they encourage them to start professional activities so that they may be responsible for paying their expenses and assisting with the household income (Guimarães \& Romanelli, 2002; Marques et al.,
2002). The experience of contributing to the family income and having children during adolescence are experiences that can precipitate the feeling of having reached adulthood, and can prejudice the engagement in other school and leisure activities (Dutra-Thomé, Cassepp-Borges, \& Koller, 2009). Young people of high SES, in turn, present higher percentages of the perception of not having reached adulthood compared to young people of low SES. The experience of EA mainly covers young people of medium and high SES (Galambos \& Martínez, 2007), in which the social and family context allows them the opportunity to experience a "juvenile moratorium" in which they can explore various experiences.

Among the results, the fact was highlighted that over $50 \%$ of the total sample reported feeling "in-between adolescence and adulthood" (Figure 1). This may indicate that the subjective mark of EA (feeling of ambivalence) manifests itself in individuals of high and low SES. Several aspects influence this scenario. The extension of the period of living with the parents has been associated with difficulty in entering the labor market and low wages (Dutra-Thomé 
et al., 2009; Zordan et al., 2009). In addition, the opening of dialogue and freedom of the children inside the home can generate a new form of transition to adulthood. Traditional family values coexist with the individual values of each family member, which may influence the manifestation of feelings of ambivalence in the emerging adults (Borges \& Magalhães, 2009; Vieira \& Rava, 2010; Zordan et al., 2009).

Considering the nine criteria investigated for achieving adulthood, the higher frequencies presented by the young people of the low SES group in relation to the criterion "becoming capable of caring for the parents" compared to the other group, may be related to the strong sense of family obligations present in Latin-American youths (Arnett, 2003). It is pertinent to consider that the sense of family obligations includes other elements, such as a greater emphasis on marriage and the decision to have children. In the United States, for example, young people of African and Latin origins perceive themselves as adults before other young people, due to aspects associated with growing up in families of low SES and assuming adult responsibilities, such as having children (Arnett, 2003). Furthermore, individuals of low SES live in contexts of mutual support among family members. Commonly, they live with other family members and relatives (e.g., parents, grandparents, siblings and cousins) who are financially dependent on each other (Aquino et al., 2003; Bem \& Wagner, 2006).

When asked about the most important criteria for achieving adulthood, considering the total sample, the criterion "accepting responsibility for oneself" was identified as the most important to reach adulthood, followed by "becoming financially independent" and "completing education". The first and second criteria are in line with studies on EA in the United States (Arnett, 2011), however, the third criterion differs. The importance of this aspect in the Brazilian context may be associated with difficulties of access to higher levels of educational. In this regard, in recent years, government actions have sought to facilitate the access of young people of low SES to university education through initiatives such as the University for All Program - ProUni (Ministry of Education, 2011), which offers scholarships for private higher education institutions.

Young people of high SES present greater access to technological tools, which can lead them to greater integration in the globalized world. The globalized identity is becoming more prevalent worldwide, there is an intense interaction between different cultures, increased migration, and the dispersion of global media and international commerce (Jensen, 2012). These interactions influence the proper psychological development of individuals and the manifestation of a new dynamic of transition to the adult life. The proposition of EA as a new period of development seems to capture these features. Thus, it is possible the increased access that young people of high SES have to technology encourages the experience of EA, especially due to the possibility of living a globalized identity.

\section{Conclusion}

The present study investigated the transition to adulthood of Brazilian young people from the perspective of EA. By considering the socioeconomic characteristics of the participants, it was highlighted that developmental stages, such as EA, are relevant references, but that they only make sense if investigated in the context. Thus, nuances and particularities inherent to the spaces of developments of the participants allowed differences between them to be identified, especially the greater chance that young people of high SES experience a period of exploration of their identities, with institutional support, especially from the family (Arnett, 2011; Demuth \& Keller, 2011; Galambos \& Martínez, 2007; Henriques, Jablonski, \& Feres-Carneiro, 2004; IBGE, 2013).

This finding appears to identify that young people of low SES assumed adult roles earlier (e.g., working to assist with the household income, marriage/cohabitation and living alone). These responsibilities negatively affect their dedication to their studies, and they presented higher levels of school year repetition. In addition, these youths reported higher frequencies of the perception of having already reached adulthood compared to the young people of high SES.

Despite the economic factor having influenced the transition to adulthood of these groups, more than $50 \%$ of the total sample reported perceiving themselves as in-between adolescence and adulthood - an indicator of the existence of EA in the subjects of both SES. This result was associated with the prolongation of the period of the young person residing in the parental home (Borges \& Magalhães, 2009; IBGE, 2013; Vieira \& Rava, 2010; Zordan et al., 2009), a situation with different motivations, such as financial difficulties, freedom and autonomy of children in the home, greater dedication to their studies, and the need to contribute to the family income - the latter more associated with young people of low SES.

Regarding the limitations, this study was restricted to the urban context of the Brazilian South, therefore it can not be inferred that the same findings will be found in other regions of the country. Furthermore, it was an exploratory cross-sectional study on a topic not yet studied in the country, EA. Thus, it is necessary for other studies that consider this theme to be developed in the country, in order to ascertain whether young people from high SES are more likely to experience EA, or whether the phenomenon is absent in young people of low SES. Future studies that include other regions and populations of young people in situations of social vulnerability may provide a more comprehensive overview of the various transitions to adulthood present in a context as diverse as that of Brazil.

Young people of both SES may benefit from public policies and institutional support to deal with the challenges of the transition to adulthood. identified from the perspective of EA as: (a) coping with feelings of insecurity about the instability they face in various fields of life (love, family 
and professional); (b) overcoming educational deficiencies and family and institutional support, especially in context of low SES; and (c) with less obligation and a greater ability to make decisions for themselves, managing feelings of empowerment and insecurity simultaneously.

\section{References}

Amazarray, M. R., Dutra-Thomé, L., Souza, A. P. L., Poletto, M., \& Koller, S. H. (2009). Aprendiz versus trabalhador: Adolescentes em processo de aprendizagem. Psicologia: Teoria e Pesquisa, 25(3), 329-338. doi:10.1590/S0102-37722009000300006

Aquino, E. M. L., Heilborn, M. L., Knauth, D., Bozon, M., Almeida, M. C., Araújo, J., \& Menezes, G. (2003). Adolescência e reprodução no Brasil: A heterogeneidade dos perfis sociais. Cadernos de Saúde Pública, 19(Supl. 2), S377-S388. doi:10.1590/S0102-311X2003000800019

Arias, D. F., \& Hernandez, A. M. (2007). Emerging adulthood in Mexican and Spanish youth: Theories and realities. Journal of Adolescent Research, 22(5), 476-503. doi:10.1177/0743558407305774

Arnett, J. J. (2003). Conceptions of the transition to adulthood among emerging adults in American ethnic groups. New Directions in Child and Adolescent Development, (100), 63-75. doi:10.1002/cd.75

Arnett, J. J. (2005). The developmental context of substance abuse in emerging adulthood. Journal of Drug Issues, 35(2), 235-254. doi:10.1177/002204260503500202

Arnett, J. J. (2010). The self. In Adolescence and emerging adulthood: A cultural approach (4th ed., pp. 146-173). Upper Saddle River, NJ: Prentice Hall.

Arnett, J. J. (2011). Emerging adulthood(s): The cultural psychology of a new life stage. In J. A. Lene (Ed.), Bridging cultural and developmental approaches to psychology: New synthesis in theory, research, and policy (pp. 255-275). New York, NY: Oxford University Press.

Arnett, J. J., \& Eisenberg, N. (2007). Introduction to the special section: Emerging adulthood around the world. Child Development Perspectives, 1(2), 66-67. doi:10.1111/j.1750-8606.2007.00015.x

Arnett, J. J., \& Tanner, J. L. (2011). Themes and variation in emerging adulthood across social classes. In J. J. Arnett, M. Kloep, L. B. Hendry, \& J. L. Tanner (Eds.), Debating emerging adulthood: Stage or process? (pp. 31-50). New York, NY: Oxford University Press.

Associação Brasileira dos Institutos de Pesquisa de Mercado. (2008). Critério de classificação socioeconômico do Brasil (CCSEB). São Paulo, SP: ABA/ANEP/ABIPEM.

Bem, L. A., \& Wagner, A. (2006). Reflexões sobre a construção da parentalidade e o uso de estratégias educativas em famílias de baixo nível socioeconômico. Psicologia em Estudo, 11(1), 63-71. doi:10.1590/S1413-73722006000100008
Borges, C. C., \& Magalhães, A. S. (2009). Transição para a vida adulta: Autonomia e dependência na família. Psico, 40(1), 42-49. Retrieved from http:// revistaseletronicas.pucrs.br/ojs/index.php/revistapsico/ article/viewFile/3993/4140

Câmara, S. G., Castellá Sarriera, J., \& Pizzinato, A. (2004). Que portas se abrem no mercado de trabalho para os jovens em tempos de mudança? In J. Castellá Sarriera, K. B. Rocha, \& A. Pizzinato (Orgs.), Desafios do mundo do trabalho: Orientação, inserção e mudanças (pp. 73-114). Porto Alegre, RS: EDIPUCRS.

Casal, C. L. F., \& Farias, L. S. (2005). Família, adolescência e juventude: Desafios e aprendizados da rede solidária de defesa social. In C. Rique \& N. Lima (Eds.), Juntando saberes e construindo práticas (pp. 57-64). Recife, PE: Bagaço.

Conselho Federal de Psicologia. (2000). Resolução CFP No. 016, de 20 de dezembro de 2000. Dispõe sobre a realização de pesquisa em Psicologia com seres humanos. Brasília, DF: CFP.

Dell'Aglio, D. D., Koller, S. H., Cerqueira-Santos, E., \& Colaço, V. F. R. (2011). Revisando o questionário da juventude brasileira: Uma nova proposta. In D. D. Dell'Aglio \& S. H. Koller (Orgs.), Adolescência e juventude: Vulnerabilidade e contextos de proteção (pp. 259-270). São Paulo, SP: Casa do Psicólogo.

Demuth, C., \& Keller, H. (2011). Culture, learning, and adult development. In C. Hoare (Ed.), The Oxford handbook of reciprocal adult development and learning (2nd ed., pp. 425-443). New York, NY: Oxford University Press.

Dutra-Thomé, L. D., Cassepp-Borges, V., \& Koller, S. H. (2009). A juventude brasileira no mundo do trabalho: Proteção e vulnerabilidade social. In R. M. C. Libório \& S. H. Koller (Orgs.), Adolescência e juventude: Risco e proteção na realidade brasileira (pp. 265-292). São Paulo, SP: Casa do Psicólogo.

Erikson, E. H. (1950). Infância e sociedade. Rio de Janeiro, RJ: Zahar.

Erikson, E. H. (1968). Identidade: Juventude e crise. Rio de Janeiro, RJ: Zahar.

Facio, A., Resett, S., Micocci, F., \& Mistrorigo, C. (2007). Emerging adulthood in Argentina: An age of diversity and possibilities. Child Development Perspectives, 1(2), 115-118. doi:10.1111/j.1750-8606.2007.00025.x

Galambos, N. L., \& Martínez, M. L. (2007). Poised for emerging adulthood in Latin America: A pleasure for the privileged. Child Development Perspectives, 1(2), 109-114. doi:10.1111/j.1750-8606.2007.00024.x

Goldscheider, F., \& Goldscheider, C. (1994). Leaving and returning home in 20th century America (Population Bulletin, Vol. 4, No. 4). Washington, DC: Population Reference Bureau.

Guimarães, R. M., \& Romanelli, G. (2002). A inserção de adolescentes no mercado de trabalho através de uma ONG. Psicologia em Estudo, 7(2), 117-126. doi:10.1590/S1413-73722002000200014 
Henriques, C. R., Jablonski, B., \& Feres-Carneiro, T. (2004). A "geração cangurú": Algumas questões sobre o prolongamento da convivência familiar. Psico, 35(2), 195-205.

Instituto Brasileiro de Geografia e Estatística. (2011). Pesquisa Nacional por Amostra de Domicílios (PNAD). Rio de Janeiro, RJ: IBGE.

Instituto Brasileiro de Geografia e Estatística. (2013). Pesquisa Nacional por Amostra de Domicílios (PNAD). Rio de Janeiro, RJ: IBGE.

Jensen, L. A. (2012). Bridging universal and cultural perspectives: A vision for developmental psychology in a global world. Child Development Perspectives, 6(1), 98-104. doi:10.1111/j.1750-8606.2011.00213.x

Lopes, E. A. B. (2012). Reestruturação produtiva e transformações recentes no mercado de trabalho: Mudanças no mercado de trabalho no Brasil e em Goiás dos anos 90. Revista de Administração da UEG, 3(1), 118-138. Retrieved from http://www.prp.ueg.br/revista/index.php/ revista_administracao/article/view/1185/pdf

Margulis, M., \& Urresti, M. (2008). La juventud es más que una palavra. In M. Margulis (Ed.), La juventud es más que una palabra: Ensayos sobre cultura y juventud (3rd ed., pp. 13-30). Buenos Aires, Argentina: Biblos.

Marques, M. E., Neves, M. A., \& Carvalho Neto, A. (2002). Trabalho infantil: A infância roubada. Belo Horizonte, MG: Segrac.

Ministério da Educação. (2011). Censo da Educação Superior de 2009. Brasília, DF: Ministério da Educação/INEP.

Ministério da Saúde. Conselho Nacional de Saúde. (1996). Resolução No. 196, de 10 de outubro de 1996. Aprova diretrizes e normas regulamentadoras de pesquisas envolvendo seres humanos. Brasília, DF: CNS.

Vieira, A. C. S., \& Rava, P. G. S. (2010). Ninho cheio: Uma nova etapa do ciclo vital familiar? Barbaroi, 33, 118-134. Retrieved from http://pepsic.bvsalud. org/scielo.php?script $=$ sci_arttext\&pid $=$ S 0104 $65782010000200008 \& \operatorname{lng}=$ pt $\&$ nrm $=$ isso

Zordan, E. P., Falcke, D., \& Wagner, A. (2009). Casar ou não casar? Motivos e expectativas com relação ao casamento. Psicologia em Revista, 15(2), 56-76. Retrieved from http://pepsic.bvsalud.org/pdf/per/v15n2/v15n2a05.pdf
Luciana Dutra-Thomé is a postdoctoral student of the Graduate Program in Psychology at the Universidade Federal do Rio Grande do Sul.

Silvia Helena Koller is a Professor of the Instituto de Psicologia at the Universidade Federal do Rio Grande do Sul.

Received: Apr. 9, 2013

1st Revision: Mar. 21, 2014

Approved: June 25, 2014

How to cite this article:

Dutra-Thomé, L., \& Koller, S. H. (2014). Emerging adulthood in Brazilians of differing socioeconomic status: Transition to adulthood. Paidéia (Ribeirão Preto), 24(59), 313-322. doi: 10.1590/1982-43272459201405 